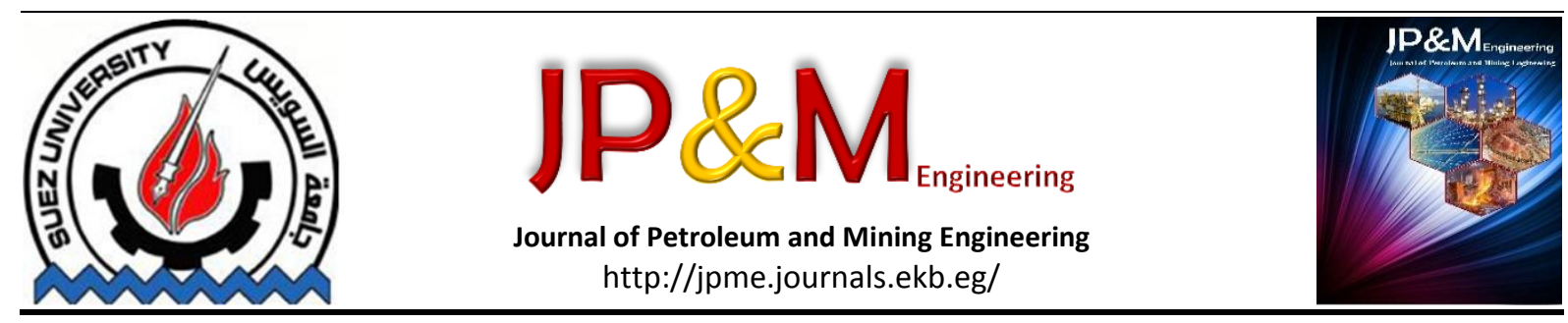

\title{
Effect of Components Concentration of ASP Chemical Flooding Solution on the Phase Behavior (Oil/ASP)
}

\author{
Mosab Badr Aldin Albredi \\ Faculty Of Petrochemical Engineering-Alfurat University- Syria
}

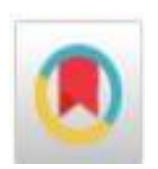

\begin{abstract}
In this research, the effects of the following factors on phase behavior of Oil/ASP solution were studied: Change of DDBSCa concentration in ASP solution on phase behavior of (Oil/ASP); Change of $\mathrm{Na} 2 \mathrm{CO} 3$ concentration in ASP solution on phase behavior of (Oil/ASP) and Change of Xanthan Gum concentration in ASP solution on phase behavior of (oil /ASP). Later The optimum concentrations of ASP components were restricted depending on phase behaviour The researcher has investigated this effect By studying change each of :oleic phase volume (Voleic) that result of emulsification between the oil and ASP solution - ASP solution volume that form emulsifier (Vd) .

By relationship with (VASP\%) which means : the percentage of ASP solution volume that added to the total volume (Oil+ASP solution).

The results referred to the following : the Miscibility of (ASP \Oil) is affected strongly by components concentration of ASP solution. Also, The optimum concentrations of ASP solution components that achieve successful ASP flooding depending on phase behavior are compatible with the concentrations that I found from my previous studies that achieved : minimum interfacial tension at minimum concentration (regarding surfactant and alkaline). Maximum viscosity compatible with oil viscosity of the studied oil field (regarding the polymer).
\end{abstract}

\section{Keywords}

Miscibility; aqueous emulsifier phase; oil phase ASP solution; phase behavior

\section{Introduction}

Surfactants (S), Polymers (P), and Alkalines (A) construct the main components of all chemical methods of enhanced oil recovery, the reactions of these chemical materials may be very important for the final results of the field experiments in that it may enhance or decrease the desired effect of each chemical material when chemical patches mix in the reservoir. [1]

In some cases, it may be requested to inject these chemicals simultaneously in the same patch as it is in the ASP injection method in order to have a mutual effect (a larger decrease of interfacial tension and decrease the motility ratio as well as emulsifying oil and altering wet ability) that in turn decreases injection time and therefore develops this process economically. [2]

The Chemical Injection Method (ASP) is considered modern in the Enhanced Oil Recovery that developed from: Polymer, Alkaline and Surfactant Injection Method. It combines the advantages of all these methods, therefore, we can benefit from the combination of polymer, alkaline and surfactant. [3]
Currently, this method receives a great attention in regards to research and application. The use of these chemicals together may achieve high recovery factor with a relatively low cost due to the use of the low-cost alkaline that in turn reduces the use of the expensive surfactants that serves the same purpose with high efficiency. Taking into consideration the importance of polymer presence in the injection solution of ASP. [4] The enhanced oil recovery methods vary in its mechanisms of influence. The ASP injection method aims to enhance the hydraulic of formation fluids by affecting the following mechanisms:

- $\quad$ Reducing the interfacial tension between oil and water.

- $\quad$ Reducing the mobility ratio between oil and water.

- Increasing the capillary number (Nc).

- Emulsification of oil.

- Wet ability alteration. 


\section{The Purpose of this research :}

The study of the phase-behavior and preparation of the deeded data at the phase-balance of the mixture is considered vital to configure a system that decreases the volume of the multi-phase area while increases the volume of the single-phase area. Determination of phase-behavior is very important for interpretation of displacement processes; in addition, correlation the output of displacement processes with phase behavior is very critical for the successful running of the ASP chemical injection process. And due to injection of surfactant, alkaline and polymer solution depends on principle of the miscibility displacement (achieving greater decrease of the interfacial tension ("Oil/Water") and thus, approaching the status of complete mixing that results in increase of the volume of single-phase area.

Due to all the aforementioned reasons, it was necessary to carry out this study. The composition of ASP solution in this research is:

Alkaline: $\mathrm{Na} 2 \mathrm{CO} 3$, concentration $0.7 \%$ wt.

Surfactant: DDBSCa (Wetconat P1220EH), concentration $0.05 \% \mathrm{wt}$.

Polymer: Xanthan Gum, concentration 550 ppm.

These types and its optimum concentrations were chosen from previous lab studies which I preformed previously depending on the surface tension and viscosity characteristics of the ASP solution. In other meaning, the optimum concentration of both the surfactant and alkaline that achieve lower surface tension of the ASP solution and the optimum concentration of the polymer that gives higher viscosity of the ASP solution as well.

\section{Literature Review :}

- $\quad$ Pop \& Nelson presented lab results in which the phase behavior plays an essential role in oil recovery by chemical displacement. [5]

- Shuler and his colleagues showed that the tests on the phase behavior and interfacial tension (IFT) gives a useful practical evidence that can be employed in design or success of any displacement process by chemicals. [6]

- Sayyouh showed that salinity and temperature increase the amount of surfactant requested to form a stable-micro emulsion, as water salinity increases the two and three-phase areas increase, whereas the single-phase-micro emulsion decreases. He also showed that temperature increase causes increase of the volume of two and three-phase areas. [7]

- Nelson found that the optimum salinity is relevant to the concentration of the surfactant and it decreases to low values at low concentration of the surfactant. [8]

- A.M.Attia concluded that the volume of the single-phase decreases by increasing salinity concentration in the solution. He also concluded from his lab study that temperature increasing from lab temperature (60 oF) to the studied formation temperature (160 oF) caused decrease of the oil/water mixing. Furthermore, he found that the effect of Iso-propanol on the phase behavior by using the PETROSTEP surfactant is successful because the miscibility increases by increasing the concentration of the said alcohol until the percentage of $36 \%$. [9]

- Ronald and Mauran showed that phase behavior enhances as the temperature increases or adding alcohol by decreasing the extremely highdensity phase like a gelatin, sediments and the like, however, if the alcohol is not, the system has to be balanced by mixing two or more of the surface-active materials. [10]

- Healy noticed solutions viscosity decrease when tri-amino-alcohol (TAA) is added to the systems he experimented. The (TAA) increased the volume of the water area as an external phase in the triple-phase diagram. He also mentioned that the associated surfactants increased solfonate solubility in water and decreased adsorption onto the reservoir rocks. [11]

- Slater showed that phase behavior of systems containing more than one surfactant is very sensitive towards the composition of the surfactants mix. That conclusion implies that small amounts of surfactant may have considerable effects on the phase behavior and physical properties of the system. [12]

- Krumrine also concluded through chemical displacement process by surfactant, polymer and alkaline that the effect of these substances on each other may be very important in regards to the final results of the field experiments, he also showed that injecting of these chemicals simultaneously in the same patch decreases the injecting time and thereby enhances the process economically. [13]

- Demin Wand, Wanli Kang showed through ongoing-field-tracking experiments about ASP injection the presence of three types of crude oil emulsifiers by means of the lab devices which are: water/oil emulsion, oil/water emulsion and oil/water/oil multiple emulsions. They also concluded that the relatively easy formation of the emulsion between alkalines and crude oil resulted from the fact that surface-active environment in the place where alkalines and materials included in oil react. [14]

- J.Coxly, Matrine showed in their study about the influence of variety of alkalines on the phase behavior of mixtures (oil/formation water/surfaceactive material) that the phase behavior of the studied system is sensitive against type of the added alkali cation, potassium, for instance, has a greater effect than sodium where ammonium has the lowest effect. They also concluded that the phase behavior is not sensitive against alkalic anions. [15]

- Ashrawi found during his study about the influence of phase behavior (surfactants/oil/formation water) on the production by chemical injection that two parameters dominate the system composition which are: salinity of 
formation water and the apparent equivalent weight of the sulfonates mixture. [16]

- Trushenski noticed that adding polymer to the surfactant solution decreases the miscibility and that believed to be related to sulofonates incompatibility with polymer. This incompatibility is due to several factors: salinity, polymer concentration and surfactant concentration.[17]

- Szabo provided data about several additional polymers and sulfonates. Types of polymers were: Xanthan Gum, PAM. All Szabo mixtures were consists of two or three phases which contradicts Trushenski results. One cause of that contradiction was the relatively high salinity that Szabo used in most of his samples. [18]

\section{The lab study:}

The lab study was performed in two Maine stages:

\section{*First stage:}

Studying the effect of the concentration change of surfactant, alkaline and polymer in the ASP solution on the phase behaviour (oil/ASP solution).

\section{*Second stage:}

Determination of the optimum concentration of each P-S- A within the ASP solution from the point of view of the phase behavior.

\section{*The first stage:}

Studying the effect of the concentration change of surfactant, alkaline and polymer in the ASP solution on the phase behavior (oil/ASP solution).

The phase volumes formed due to mix property (oil/ASP) and resulted from the presence of the surfactant and alkaline (emulsification factor) are influenced by several factors, some of them are:

1. Oil and water phase ratio.

2. Concentration of $(P, S$, and $A)$ in individual in the ASP solution.

3. Temperature and salinity.

I studied in the research the first and the second, however, due to its importance, I assigned an independent chapter for temperature and salinity

The change in the phase volumes can be studied by the traditional phase-triangle method, but we will perform this study by other method, the proposed method is faster, simpler and more precise.

\section{Procedures:}

4. Several points are chosen with different volume ratios of the added oil (Voil) and ASP solution (VASP) as in table (1).

5. In $(50 \mathrm{~cm} 3)$ glass cylinders, the mixtures are prepared (oil-ASP solution) according to the ratios mentioned in the table with different concentrations for each $(P, S$, and $A)$ as we will see later. Then the cylinders closed tight with sealed caps.

6. The prepared mixtures are blended using a rotational blender on a slow speed for 24 hours straight.

7. Once the blending is over, the mixtures are left for 24 hours to reach equilibrium.

8. The volume of the formed oleic phase (Voleic) and the volume of the residual ASP solution (Vaquas) are measured.

9. Results are organized in tables and presented graphically.

Table 1 Chosen points for study.

\begin{tabular}{|c|c|c|}
\hline $\begin{array}{c}\text { Point } \\
\text { No. }\end{array}$ & $\begin{array}{c}\text { Volumetric percent of } \\
\text { the added ASP solution } \\
\text { (VASP\%vol) }\end{array}$ & $\begin{array}{c}\text { Volumetric percent of } \\
\text { the added oil } \\
\text { (Voil\%vol) }\end{array}$ \\
\hline 1 & 10 & 90 \\
\hline 2 & 20 & 80 \\
\hline 3 & 30 & 70 \\
\hline 4 & 40 & 60 \\
\hline 5 & 50 & 50 \\
\hline 6 & 60 & 40 \\
\hline 7 & 70 & 30 \\
\hline 8 & 80 & 20 \\
\hline 9 & 90 & 10 \\
\hline
\end{tabular}

The following Symbols and terminology will be used in this study:

- Voil: volume of the added oil . (cm3).

- Voil \%: the percentage of the added oil to the total volume. \%( \%vol)

- VASP : volume of the ASP solution that contains the optimum concentrations . $(\mathrm{cm} 3)$.

- VASp \%: the percentage of the added ASP solution to the total volume. ( $\% \mathrm{vol})$.

- $\quad$ VT : the total volume (Voil+VASP).(cm3).

- Voleic: volume of the one-phase area (oil+ASP solution) formed after mixing. (cm3).

- Vaquas: volume of the residual ASP solution after mixing. ( $\mathrm{cm} 3)$.

- Vd= Voil - Voleic: volume of the ASP solution that forms the single phase area. $(\mathrm{cm} 3)$.

- Equations:

- $\quad \mathrm{VT}=$ Voil +VASP

- $\quad \mathrm{Vd}=$ Voleic-Voil or Vd=VASP -Vaquas

- $\quad$ Voleic $=$ Voil + Vd

The following figure illustrates the aforementioned Symbols and terminology: 


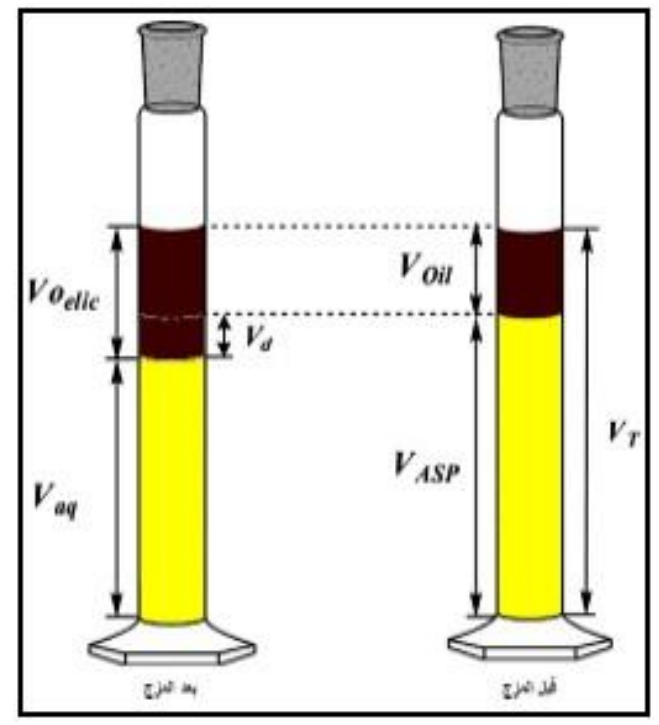

Figure 1 change of the phases volumes after mixing

Firstly: effect of concentration change of DDBSCa (Wetconat1220EH) surfactant in the ASP solution on the phase behavior (oil/ASP):

This study was performed through: studying the change of both the resulted oil phase volume (Voleic) and the volume of ASP solution that forms the emulsification ( $\mathrm{Vd}$ ) by relationship with (VASP\%) at different concentrations of the DDBSCa (Wetconat1220EH) surfactant.

Concentrations proposed for study:

$\mathrm{CS} 1=0.03 \% w t, \mathrm{CS} 2=0.05 \% w t, \mathrm{CS} 3=0.1 \% w t, \mathrm{CS} 4=$ $0.2 \% w t$

According to the stages of performing the proposed method, I have reached to the results shown in the following tables:

Table 2 The results at concentration (CS1=0.03\%wt) of the DDBSCa (Wetconat 1220EH) surfactant

\begin{tabular}{|c|c|c|c|c|c|c|}
\hline $\begin{array}{c}\text { Sample } \\
\text { No. }\end{array}$ & $\begin{array}{l}\text { VASP } \\
(\mathrm{cm} 3)\end{array}$ & $\begin{array}{c}\text { Voil } \\
(\mathrm{cm} 3)\end{array}$ & $\begin{array}{l}\text { Vaquas } \\
(\mathrm{cm} 3)\end{array}$ & \begin{tabular}{|l|} 
Voleic \\
$(\mathrm{cm} 3)$
\end{tabular} & \begin{tabular}{|c|}
$\mathrm{Vd}$ \\
$(\mathrm{cm} 3)$
\end{tabular} & Remarks \\
\hline 1 & 5 & 45 & 2.5 & 47.5 & 2.5 & \multirow{9}{*}{$\begin{array}{c}\text { Cylinder Volume: } \\
50 \mathrm{~cm} 3 \mathrm{CS} 1=0.03 \% \mathrm{wt} \\
\mathrm{CA}=\text { Const }=0.7 \% \mathrm{wt} \\
\mathrm{CP}=\text { Const }=550 \mathrm{ppm} \\
\mathrm{T}=33 \mathrm{oC} \\
\text { Mixing Time }=24 \text { hours } \\
\text { DERO Oil Field }\end{array}$} \\
\hline 2 & 10 & 40 & 5 & 45 & 5 & \\
\hline 3 & 15 & 35 & 7 & 43 & 8 & \\
\hline 4 & 20 & 30 & 14 & 36 & 6 & \\
\hline 5 & 25 & 25 & 19.5 & 30.5 & 5.5 & \\
\hline 6 & 30 & 20 & 26.5 & 23.5 & 3.5 & \\
\hline 7 & 35 & 15 & 32 & 18 & 3 & \\
\hline 8 & 40 & 10 & 38.5 & 11.5 & 1.5 & \\
\hline 9 & 45 & 5 & 45 & 5 & 0 & \\
\hline
\end{tabular}

Table 3 The results at concentration ( $\mathrm{CS} 2=0.05 \% \mathrm{wt}$ ) of the DDBSCa (Wetconat 1220EH) surfactant.

\begin{tabular}{|c|c|c|c|c|c|c|}
\hline $\begin{array}{c}\text { Sample } \\
\text { No. }\end{array}$ & $\begin{array}{l}\text { VASP } \\
(\mathrm{cm} 3)\end{array}$ & $\begin{array}{c}\text { Voil } \\
(\mathrm{cm} 3) \\
\end{array}$ & $\begin{array}{c}\text { Vaquas } \\
(\mathrm{cm} 3)\end{array}$ & \begin{tabular}{|l} 
Voleic \\
(cm3)
\end{tabular} & \begin{tabular}{|c|}
$\mathrm{Vd}$ \\
$(\mathrm{cm} 3)$ \\
\end{tabular} & Remarks \\
\hline 1 & 5 & 45 & 0 & 50 & 5 & \multirow{9}{*}{$\begin{array}{c}\text { Cylinder Volume: } \\
50 \mathrm{~cm} 3 \\
\mathrm{CS} 2=0.05 \% \mathrm{wt} \\
\mathrm{CA}=\text { Const }=0.7 \% \mathrm{wt} \\
\mathrm{CP}=\text { Const }=550 \mathrm{ppm} \\
\mathrm{T}=33 \text { oC } \\
\text { Mixing Time }=24 \\
\text { hours DERO Oil } \\
\text { Field }\end{array}$} \\
\hline 2 & 10 & 40 & 0 & 50 & 10 & \\
\hline 3 & 15 & 35 & 0 & 50 & 15 & \\
\hline 4 & 20 & 30 & 7.5 & 42.5 & 12.5 & \\
\hline 5 & 25 & 25 & 15 & 35 & \begin{tabular}{|c|}
10 \\
\end{tabular} & \\
\hline 6 & 30 & 20 & 22.5 & 27.5 & 7.5 & \\
\hline 7 & 35 & 15 & 30 & 20 & 5 & \\
\hline 8 & 40 & 10 & 38 & 12 & 2 & \\
\hline 9 & 45 & 5 & 45 & 5 & 0 & \\
\hline
\end{tabular}

Table 4 The results at concentration (CS3 $=0.1 \% \mathrm{wt}$ ) of the DDBSCa (Wetconat 1220EH) surfactant.

\begin{tabular}{|c|c|c|c|c|c|c|}
\hline $\begin{array}{l}\text { ample } \\
\text { No. }\end{array}$ & \begin{tabular}{|l|} 
VASP \\
$(\mathrm{cm} 3)$ \\
\end{tabular} & $\begin{array}{c}\begin{array}{c}\text { Voil } \\
(\mathrm{cm} 3)\end{array} \\
\end{array}$ & \begin{tabular}{|l|} 
Vaquas \\
$(\mathrm{cm} 3)$ \\
\end{tabular} & $\begin{array}{l}\text { Voleic } \\
(\mathrm{cm} 3) \\
\end{array}$ & \begin{tabular}{|c|}
$\mathrm{Vd}$ \\
$(\mathrm{cm} 3)$ \\
\end{tabular} & $\mathrm{Re}$ \\
\hline 1 &  & 45 & & 50 & 5 & \multirow{9}{*}{$\begin{array}{c}\text { Cylinder Volume: } \\
50 \mathrm{~cm} 3 \mathrm{CS} 3=0.1 \\
\% \mathrm{wt} \\
\mathrm{CA}=\text { Const }=0.7 \% \mathrm{wt} \\
\mathrm{CP}=\text { Const }=550 \mathrm{ppm} \\
\mathrm{T}=33 \text { oC } \\
\text { Mixing Time }=24 \\
\text { hours DERO Oil } \\
\text { Field }\end{array}$} \\
\hline 2 & 10 & & & 0 & 10 & \\
\hline 3 & 15 & 35 & & 0 & 15 & \\
\hline 4 & 20 & 30 & & - & 5 & \\
\hline 5 & 25 & 25 & & 29 & 4 & \\
\hline$\overline{6}$ & 30 & 20 & 27 & 23 & 3 & \\
\hline 7 & 35 & 15 & 3 & $1 /$ & 2 & \\
\hline 8 & 40 & 10 & 39 & 11 & 1 & \\
\hline 9 & 45 & & 45 & & 0 & \\
\hline
\end{tabular}

Table 5 The results at concentration (CS4 $=0.2 \% \mathrm{wt}$ ) of the DDBSCa (Wetconat 1220EH) surfactant.

\begin{tabular}{|c|c|c|c|c|c|c|}
\hline $\begin{array}{c}\text { Sample } \\
\text { No. }\end{array}$ & $\begin{array}{l}\text { VASP } \\
(\mathrm{cm} 3)\end{array}$ & $\begin{array}{c}\text { Voil } \\
\text { (cm3) }\end{array}$ & $\begin{array}{c}\text { Vaquas } \\
(\mathrm{cm} 3)\end{array}$ & \begin{tabular}{|l} 
Voleic \\
(cm3)
\end{tabular} & $\begin{array}{c}\mathrm{Vd} \\
(\mathrm{cm} 3)\end{array}$ & Remarks \\
\hline 1 & 5 & 45 & 0 & 50 & 5 & \multirow{9}{*}{$\begin{array}{c}\text { Cylinder Volume: } \\
50 \mathrm{~cm} 3 \mathrm{CS} 4=0.2 \\
\% \mathrm{wt} \\
\mathrm{CA}=\text { Const }=0.7 \% \mathrm{wt} \\
\mathrm{CP}=\text { Const }=550 \mathrm{ppm} \\
\mathrm{T}=33 \mathrm{oC} \\
\text { Mixing Time }=24 \\
\text { hours DERO Oil } \\
\text { Field }\end{array}$} \\
\hline 2 & 10 & 40 & 0 & 50 & 10 & \\
\hline 3 & 15 & 35 & 0 & 50 & 15 & \\
\hline 4 & 20 & 30 & 18 & 32 & 2 & \\
\hline 5 & 25 & 25 & 23.5 & 26.5 & 1.5 & \\
\hline 6 & 30 & 20 & 29.5 & 20.5 & 0.5 & \\
\hline 7 & 35 & 15 & 35 & 15 & 0 & \\
\hline 8 & 40 & 10 & 40 & 10 & 0 & \\
\hline 9 & 45 & 5 & 45 & 5 & 0 & \\
\hline
\end{tabular}

At all studied concentrations, results visualization are shown on the following charts:

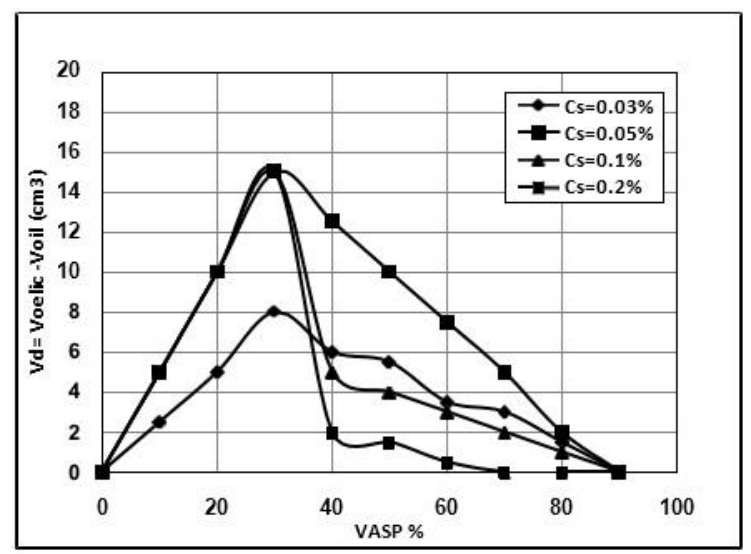

Figure $\mathbf{2}$ change of (Voleic) relationship with (VASP\%) at all studied concentrations of the DDBSCa (Wetconat 1220EH) surfactant.

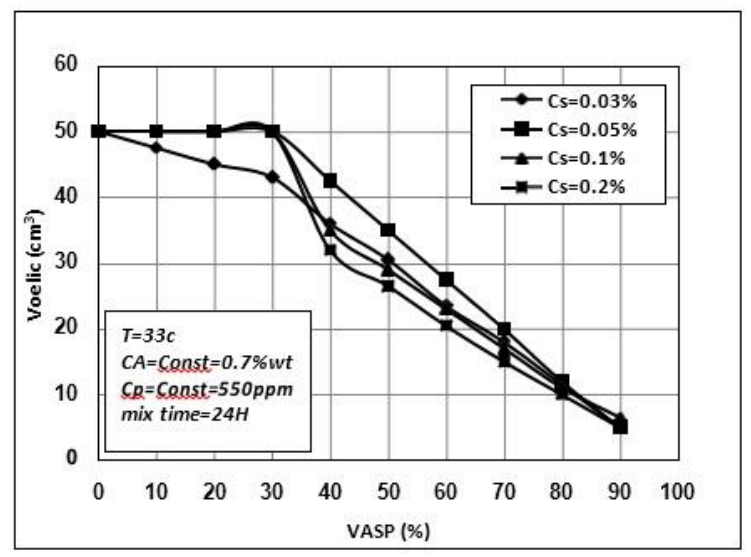

Figure 3 change of $(\mathrm{Vd})$ relationship with (VASP\%) at all studied concentrations of the DDBSCa (Wetconat 1220EH) 


\section{Discussion of the results:}

The relation (Voleic with VASP\%) at the studied concentrations of the surfactant: The results can be discussed on two stages:

The first stage: increasing (VASP\%) form 0\% to 30\%.

It's observed that the volume of the resulted single-phase area (Voleic) stays constant at a maximum value (full emulsification) for the concentrations (0.05-0.1-0.2)\%wt.

As for concentration (0.03)\%wt, the volume of the resulted single-phase area (Voleic) decreases as the (VASP\%) increases (no full emulsification in this stage at the concentration $0.03 \% \mathrm{wt}$ ).

The second stage: increasing (VASP\%) from 30\% to $90 \%$.

The volume of the resulted single-phase area (Voleic) at all studied concentrations decreases and the decrease in the volume (Voleic) is least at the concentration $0.05 \% \mathrm{wt}$, whereas, this decrease is obviously big comparing with the other studied concentrations.

The relation between (Vd and VASP\%) at the surfactant studied concentrations:

We notice increasing the admixture as the (VASP\%) increases from form $0 \%$ to $30 \%$ for all studied concentrations and this increase is less at $0.03 \% \mathrm{wt}$ concentration.

As the (VASP\%) increases more than 30\%, the admixture seems to decrease for all studied concentrations and this decrease is minimal at $0.05 \%$ wt concentration comparing with the other concentrations.

from above We conclude : the optimum concentration of the surfactant that achieves the highest value of the single-phase area represented by (Voleic) and in the same time the highest value of the admixture represented by (Vd) at all (VASP\%) studied ratios is $0.05 \%$ wt.

The increase of the surfactant concentration above $0.05 \%$ wt lead to the forming of deposited missiles of surfactant which decreases its efficiency and consequently, decreasing the miscibility

\section{Secondly: effect of ( $\mathrm{Na2} \mathrm{CO} 3$ ) concentration change} in the ASP solution on the phase behavior (oil/ASP):

This effect was studied through: studying the change of both: volume of the resulted oil phase (Voleic) and the volume of ASP solution that forms the emulsion by relationship with (VASP\%) at different concentrations (CA) of the ( $\mathrm{Na} 2 \mathrm{CO} 3$ ) alkaline.

The proposed concentrations for study are:

CA1 $=0.3 \% \mathrm{Wt}$. CA2 $=0.7 \% \mathrm{Wt}$. CA3 $=1 \% \mathrm{Wt}$. CA4 $=1.5 \%$ wt

Results of this study are presented in the following tables and figures:
Table 6 The results at concentration (CA1=0.3\%wt) of the (Na2CO3) alkaline

\begin{tabular}{|c|c|c|c|c|c|c|}
\hline $\begin{array}{c}\text { Sample } \\
\text { No. }\end{array}$ & $\begin{array}{l}\text { VASP } \\
\text { (cm3) }\end{array}$ & $\begin{array}{c}\text { Voil } \\
\text { (cm3) }\end{array}$ & $\begin{array}{l}\text { Vaquas } \\
\text { (cm3) }\end{array}$ & \begin{tabular}{|l|} 
Voleic \\
(cm3)
\end{tabular} & $\begin{array}{c}\mathrm{Vd} \\
(\mathrm{cm} 3)\end{array}$ & Remarks \\
\hline 1 & 5 & 45 & 0 & 50 & 5 & \multirow{9}{*}{$\begin{array}{c}\text { Cylinder Volume: } \\
50 \mathrm{~cm} 3 \mathrm{CA} 1=0.3 \\
\% \mathrm{wt} \\
\mathrm{CS}=\text { Const }=0.05 \\
\% \mathrm{wt} \\
\mathrm{CP}=\text { Const }=550 \\
\text { ppm T=33 oC } \\
\text { Mixing Time }=24 \\
\text { hours DERO Oil } \\
\text { Field }\end{array}$} \\
\hline 2 & 10 & 40 & 0 & 50 & 10 & \\
\hline 3 & 15 & 35 & 2 & 48 & 13 & \\
\hline 4 & 20 & 30 & 10 & 40 & 10 & \\
\hline 5 & 25 & 25 & 17 & 33 & 8 & \\
\hline 6 & 30 & 20 & 24.5 & 25.5 & 5.5 & \\
\hline 7 & 35 & 15 & 32 & 18 & 3 & \\
\hline 8 & 40 & 10 & 39 & 11 & 1 & \\
\hline 9 & 45 & 5 & 45 & 5 & 0 & \\
\hline
\end{tabular}

Table 7 The results at concentration $(\mathrm{CA} 2=0.7 \% \mathrm{wt})$ of the ( $\mathrm{Na2} \mathrm{CO} 3$ ) alkaline.

\begin{tabular}{|c|c|c|c|c|c|c|}
\hline $\begin{array}{c}\text { Sample } \\
\text { No. } \\
\end{array}$ & $\begin{array}{l}\text { VASP } \\
(\mathrm{cm} 3) \\
\end{array}$ & \begin{tabular}{|c|c} 
Voil \\
(cm3) \\
\end{tabular} & \begin{tabular}{|l} 
Vaquas \\
$(\mathrm{cm} 3)$
\end{tabular} & $\begin{array}{l}\text { Voleic } \\
(\mathrm{cm} 3) \\
\end{array}$ & $\begin{array}{c}\mathrm{Vd} \\
(\mathrm{cm} 3)\end{array}$ & ema \\
\hline 1 & 5 & 45 & 0 & 50 & 5 & \multirow{9}{*}{$\begin{array}{c}\text { Cylinder Volume: } \\
50 \mathrm{~cm} 3 \mathrm{CA} 2=0.7 \\
\% \mathrm{wt} \\
\mathrm{CS}=\text { Const }=0.05 \% \mathrm{wt} \\
\mathrm{CP}=\text { Const }=550 \mathrm{ppm} \\
\mathrm{T}=33 \text { oC } \\
\text { Mixing Time }=24 \\
\text { hours DERO Oil Field }\end{array}$} \\
\hline 2 & 10 & 40 & 0 & 50 & 10 & \\
\hline 2 & 15 & 35 & 0 & 50 & 15 & \\
\hline 4 & 20 & 30 & 7.5 & 42.5 & 12.5 & \\
\hline 5 & 25 & 25 & 15 & 35 & 10 & \\
\hline 6 & 30 & 20 & 23 & 27 & 7 & \\
\hline 7 & 35 & 15 & 30 & 20 & 5 & \\
\hline 8 & 40 & 10 & 38 & 12 & 2 & \\
\hline$y$ & 45 & 5 & 45 & 5 & 0 & \\
\hline
\end{tabular}

Table 8 The results at concentration ( $\mathrm{CA} 3=1 \% \mathrm{wt}$ ) of the $(\mathrm{Na} 2 \mathrm{CO} 3)$ alkaline.

\begin{tabular}{|c|c|c|c|c|c|c|}
\hline $\begin{array}{c}\text { Sample } \\
\text { No. }\end{array}$ & $\begin{array}{l}\text { VASP } \\
(\mathrm{cm} 3) \\
\end{array}$ & \begin{tabular}{|c|c}
$\begin{array}{c}\text { Voil } \\
\text { (cm3) }\end{array}$ \\
\end{tabular} & \begin{tabular}{|l|} 
Vaquas \\
$(\mathrm{cm} 3)$
\end{tabular} & $\begin{array}{l}\text { Voleic } \\
\text { (cm3) }\end{array}$ & $\begin{array}{c}\mathrm{Vd} \\
(\mathrm{cm} 3)\end{array}$ & Remarks \\
\hline 1 & 5 & 45 & 0 & 50 & 5 & \multirow{9}{*}{$\begin{array}{c}\text { Cylinder Volume: } \\
50 \mathrm{~cm} 3 \mathrm{CA} 3 \\
=1 \% \mathrm{wt} \\
\mathrm{CS}=\text { Const }=0.05 \\
\% \mathrm{wt} \\
\mathrm{CP}=\text { Const }=550 \\
\text { ppm } \mathrm{T}=33 \text { oC } \\
\text { Mixing Time }=24 \\
\text { hours DERO Oil } \\
\text { Field }\end{array}$} \\
\hline$\overline{2}$ & $\overline{10}$ & 40 & 0 & 50 & 10 & \\
\hline 3 & $\overline{15}$ & 35 & 0 & 50 & 15 & \\
\hline 4 & 20 & 30 & 4.5 & 45.5 & 15.5 & \\
\hline 5 & 25 & 25 & 13.5 & 36.5 & 11.5 & \\
\hline$\overline{6}$ & 30 & 20 & 21 & 29 & 9 & \\
\hline 7 & 35 & 15 & 29 & 21 & 6 & \\
\hline 8 & 40 & 10 & 37 & 13 & 3 & \\
\hline 9 & 45 & 5 & 45 & 5 & 0 & \\
\hline
\end{tabular}

Table 9 The results at concentration (CA4=1.5 \%wt) of the (Na2CO3) alkaline.

\begin{tabular}{|c|c|c|c|c|c|c|}
\hline $\begin{array}{c}\text { Sample } \\
\text { No. }\end{array}$ & $\begin{array}{l}\text { VASP } \\
(\mathrm{cm} 3)\end{array}$ & \begin{tabular}{|l|} 
Voil \\
$(\mathrm{cm} 3)$
\end{tabular} & $\begin{array}{c}\text { Vaquas } \\
\text { (cm3) }\end{array}$ & $\begin{array}{l}\text { Voleic } \\
\text { (cm3) }\end{array}$ & $\begin{array}{c}\mathrm{Vd} \\
(\mathrm{cm} 3)\end{array}$ & Remarks \\
\hline 1 & 5 & 45 & 0 & 50 & 5 & \multirow{9}{*}{$\begin{array}{c}\text { Cylinder Volume } \\
50 \mathrm{~cm} 3 \mathrm{CA} 4=1.5 \\
\% \mathrm{wt} \\
\mathrm{CS}=\text { Const }=0.05 \\
\% \mathrm{wt} \\
\mathrm{CP}=\text { Const }=550 \\
\text { ppm T }=33 \text { oC } \\
\text { Mixing Time }=24 \\
\text { hours DERO Oil } \\
\text { Field }\end{array}$} \\
\hline 2 & 10 & 40 & 0 & 50 & 10 & \\
\hline 3 & 15 & 35 & 0 & 50 & 15 & \\
\hline 4 & 20 & 30 & 0 & 50 & 20 & \\
\hline 5 & 25 & 25 & 12 & 38 & 13 & \\
\hline 6 & 30 & 20 & 20 & 30 & 10 & \\
\hline 7 & 35 & 15 & 28 & 22 & 7 & \\
\hline 8 & 40 & 10 & 36 & 14 & 4 & \\
\hline 9 & 45 & 5 & 44 & 6 & 1 & \\
\hline
\end{tabular}

At all studied concentrations, data visualization of the results is shown in the following figures 


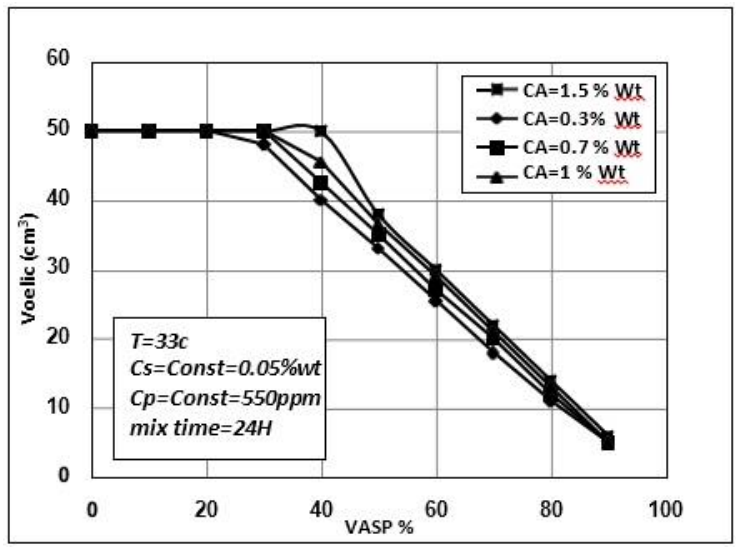

Figure 4 change of (Voleic) relationship with (VASP\%) at All the studied concentrations of ( $\mathrm{Na} 2 \mathrm{CO} 3)$ alkaline.

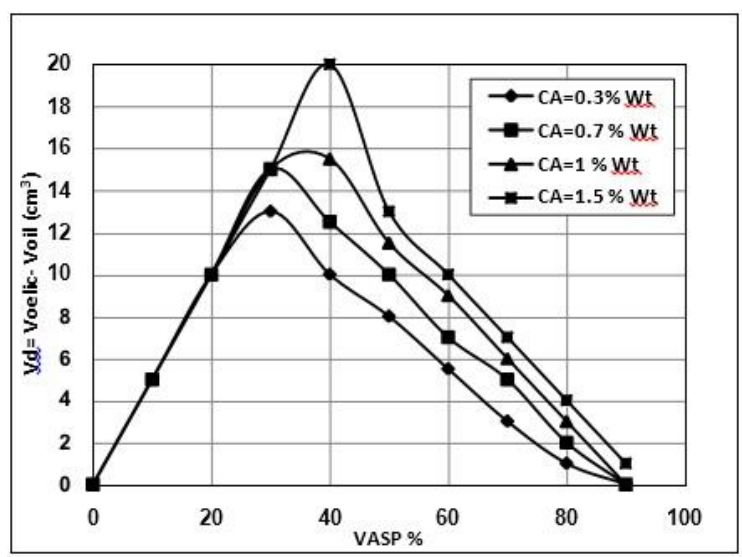

Figure 5 change of $(\mathrm{Vd})$ relationship with (VASP\%) at All the studied concentrations of ( $\mathrm{Na2} \mathrm{CO} 3)$ alkaline.

\section{Discussion of the results:}

The relation (Voleic with VASP\%) at the studied concentrations of ( $\mathrm{Na2} \mathrm{CO} 3$ ) alkaline:

It is noticed that the volume of the single-phase area (Voleic) stays constant at its max value (Full Emulsification) until the percentage (VASP $=20 \%)$ regarding the concentration $(0.3 \% \mathrm{wt})$ and until the percentage (VASP $=30 \%)$ for the concentration $(0.7 \% w t)$ and until the percentage $(\mathrm{VASP}=40 \%)$ for the concentration $(1.5 \% \mathrm{wt})$. After the percentage (VASP $=30 \%$ ) this volume decreases for all the studied concentrations. It's noticed that the greater the $\mathrm{CA}$, the less the decrease.

The relation (Vd with VASP\%) at the studied concentrations of ( $\mathrm{Na2} \mathrm{CO} 3$ ) alkaline:

An increase in the admixture, referred to through (Vd), is occurred until it reaches its maximum value at the ration (VASP $=30 \%)$ for the two concentrations $(0.3 \%$ wt \& $0.7 \% \mathrm{wt})$, whereas it reaches its maximum value at the ratio (VASP $=40 \%)$ for the two concentrations (1\%wt \& $1.1 \% \mathrm{wt}$ ). as the (VASP) increases above the said ratio, a gradual decrease of the admixture is noticed for all the studied concentrations. The greater the CA, the less the decrease.

from above We conclude: that both volume of the singlephase area (Voleic) and volume of ASP solution forming the emulsification $(\mathrm{Vd})$ are proportional the ( $\mathrm{Na2} \mathrm{CO} 3)$ alkaline concentration in the ASP solution. The increasing concentration of the alkaline in the solution leads to more reaction with the organic acid existed in oil which in turn causes larger amount of carboxylic soap to form and consequently greater decrease of tension between surfaces that contributes in the increase of miscibility between oil and ASP solution.

Thirdly: effect of (Xanthan Gum) concentration change in the ASP solution on the phase behavior (oil/ASP):

This effect was studied through the study of the change of the resulted oil phase volume (Voleic) and the ASP solution that forms the emulsification (Vd) by relationship with (VASP\%) at different concentrations (CP) of the mentioned polymer. The proposed concentrations are:

CP1 $=550$ ppm. CP2=1000 ppm. CP3=2000 ppm. CP4=3000 ppm

Results of the study are presented in the following tables and figures:

Table 10 The results at concentration (CP1=550 ppm) of the (Xanthan Gum) polymer.

\begin{tabular}{|c|c|c|c|c|c|c|}
\hline $\begin{array}{c}\text { Sample } \\
\text { No. }\end{array}$ & $\begin{array}{l}\text { VASP } \\
(\mathrm{cm} 3)\end{array}$ & $\begin{array}{c}\text { Voil } \\
\text { (cm3) }\end{array}$ & $\begin{array}{c}\text { Vaquas } \\
(\mathrm{cm} 3)\end{array}$ & \begin{tabular}{|l|} 
Voleic \\
$(\mathrm{cm} 3)$
\end{tabular} & \begin{tabular}{|c|}
$\mathrm{Vd}$ \\
$(\mathrm{cm} 3)$
\end{tabular} & Remarks \\
\hline 1 & 5 & 45 & 0 & 50 & 5 & \multirow{9}{*}{$\begin{array}{c}\text { Cylinder Volume } \\
50 \mathrm{~cm} 3 \mathrm{CP} 1=550 \\
\text { ppm } \\
\mathrm{CS}=\text { Const }=0.05 \\
\% w t \\
\mathrm{CA}=\text { Const }=0.7 \\
\% w t \mathrm{~T}=33 \text { oC } \\
\text { Mixing Time }=24 \\
\text { hours DERO Oil } \\
\text { Field }\end{array}$} \\
\hline 2 & 10 & 40 & 0 & 50 & 10 & \\
\hline 3 & 15 & 35 & $\overline{0}$ & 50 & 15 & \\
\hline 4 & 20 & 30 & 7.5 & 42.5 & 12.5 & \\
\hline 5 & 25 & 25 & 15 & 35 & 10 & \\
\hline$\overline{6}$ & 30 & 20 & 23 & 27 & 7 & \\
\hline 7 & 35 & 15 & 30 & 20 & 5 & \\
\hline 8 & 40 & 10 & 38 & 12 & 2 & \\
\hline 9 & 45 & 5 & 45 & 5 & 0 & \\
\hline
\end{tabular}

Table 11 The results at concentration $(C P 2=1000 \mathrm{ppm})$ of the (Xanthan Gum) polymer.

\begin{tabular}{|c|c|c|c|c|c|c|}
\hline $\begin{array}{c}\text { Sample } \\
\text { No. }\end{array}$ & $\begin{array}{l}\text { VASP } \\
(\mathrm{cm} 3) \\
\end{array}$ & $\begin{array}{c}\text { Voil } \\
(\mathrm{cm} 3) \\
\end{array}$ & $\begin{array}{l}\text { Vaquas } \\
(\mathrm{cm} 3)\end{array}$ & $\begin{array}{l}\text { Voleic } \\
(\mathrm{cm} 3)\end{array}$ & \begin{tabular}{|c|}
$\mathrm{Vd}$ \\
$(\mathrm{cm} 3)$
\end{tabular} & Remarks \\
\hline 1 & 5 & 45 & 0 & 50 & 5 & \multirow{9}{*}{$\begin{array}{c}\text { Cylinder Volume: } \\
50 \mathrm{~cm} 3 \mathrm{CP} 2=1000 \\
\text { ppm } \\
\text { CS=Const }=0.05 \\
\% w t \\
\text { CA }=\text { Const }=0.7 \\
\% w t \mathrm{w}=33 \text { oC } \\
\text { Mixing Time }=24 \\
\text { hours DERO Oil } \\
\text { Field }\end{array}$} \\
\hline 2 & 10 & 40 & 0 & 50 & 10 & \\
\hline 3 & 15 & 35 & 0 & 50 & 15 & \\
\hline 4 & 20 & 30 & 10 & 40 & 10 & \\
\hline 5 & 25 & 25 & 21 & 29 & 4 & \\
\hline 6 & 30 & 20 & 27.5 & 22.5 & 2.5 & \\
\hline 7 & 35 & 15 & 33 & 17 & 2 & \\
\hline 8 & 40 & 10 & 39 & 11 & 1 & \\
\hline 9 & 45 & 5 & 45 & 5 & 0 & \\
\hline
\end{tabular}

Table 12 The results at concentration $(C P 3=2000 \mathrm{ppm})$ of the (Xanthan Gum) polymer.

\begin{tabular}{|c|c|c|c|c|c|c|}
\hline $\begin{array}{c}\text { Sample } \\
\text { No. }\end{array}$ & $\begin{array}{l}\text { VASP } \\
(\mathrm{cm} 3)\end{array}$ & $\begin{array}{l}\text { Voil } \\
\text { (cm3) }\end{array}$ & $\begin{array}{l}\text { Vaquas } \\
\text { (cm3) }\end{array}$ & $\begin{array}{l}\text { Voleic } \\
\text { (cm3) }\end{array}$ & \begin{tabular}{|c|}
$\mathrm{Vd}$ \\
$(\mathrm{cm} 3)$
\end{tabular} & Remarks \\
\hline 1 & 5 & 45 & 0 & 50 & 5 & \multirow{9}{*}{$\begin{array}{c}\text { Cylinder Volume: } \\
50 \mathrm{~cm} 3 \mathrm{CP} 3=2000 \\
\text { ppm } \\
\mathrm{CS}=\text { Const }=0.05 \\
\% \mathrm{wt} \\
\mathrm{CA}=\text { Const }=0.7 \\
\% \mathrm{wt} \mathrm{T}=33 \text { oC } \\
\text { Mixing Time }=24 \\
\text { hours DERO Oil } \\
\text { Field }\end{array}$} \\
\hline 2 & 10 & 40 & 0 & 50 & 10 & \\
\hline 3 & 15 & 35 & 0 & 50 & 15 & \\
\hline 4 & 20 & 30 & 12 & 38 & 8 & \\
\hline 5 & 25 & 25 & 23 & 27 & 2 & \\
\hline 6 & 30 & 20 & 29 & 21 & 1 & \\
\hline 7 & 35 & 15 & 34.5 & 15.5 & 0.5 & \\
\hline 8 & 40 & 10 & 40 & 10 & 0 & \\
\hline$\overline{9}$ & 45 & 5 & 45 & 5 & 0 & \\
\hline
\end{tabular}


Table 13 The results at concentration ( $C P 4=3000 \mathrm{ppm}$ ) of the (Xanthan Gum) polymer.

\begin{tabular}{|c|c|c|c|c|c|c|}
\hline $\begin{array}{c}\text { Sample } \\
\text { No. }\end{array}$ & $\begin{array}{l}\text { VASP } \\
(\mathrm{cm} 3)\end{array}$ & $\begin{array}{l}\text { Voil } \\
\text { (cm3) }\end{array}$ & $\begin{array}{l}\text { Vaquas } \\
\text { (cm3) }\end{array}$ & $\begin{array}{l}\text { Voleic } \\
(\mathrm{cm} 3)\end{array}$ & $\begin{array}{c}\mathrm{Vd} \\
(\mathrm{cm} 3)\end{array}$ & Remarks \\
\hline 1 & 5 & 45 & 0 & 50 & 5 & \multirow{9}{*}{$\begin{array}{c}\text { Cylinder Volume: } \\
50 \mathrm{~cm} 3 \mathrm{CP} 4=3000 \\
\text { ppm } \\
\text { CS }=\text { Const }=0.05 \% \\
\text { Wt CA }=\text { Const }=0.7 \\
\% \text { Wt T }=33 \text { oC } \\
\text { Mixing Time }=24 \\
\text { hours DERO Oil } \\
\text { Field }\end{array}$} \\
\hline 2 & 10 & 40 & 0 & 50 & 10 & \\
\hline 3 & 15 & 35 & 0 & 50 & 15 & \\
\hline 4 & 20 & 30 & 14 & 36 & 6 & \\
\hline 5 & 25 & 25 & 25 & 25 & 0 & \\
\hline 6 & 30 & 20 & 30 & 20 & 0 & \\
\hline 7 & 35 & 15 & 35 & 15 & 0 & \\
\hline 8 & 40 & 10 & 40 & 10 & 0 & \\
\hline 9 & 45 & 5 & 45 & 5 & 0 & \\
\hline
\end{tabular}

At all studied concentrations, data visualization of the results is shown in the following figures:



Figure 6 change of (Voleic) relationship with (VASP\%) at all studied concentrations of (Xanthan Gum) polymer.

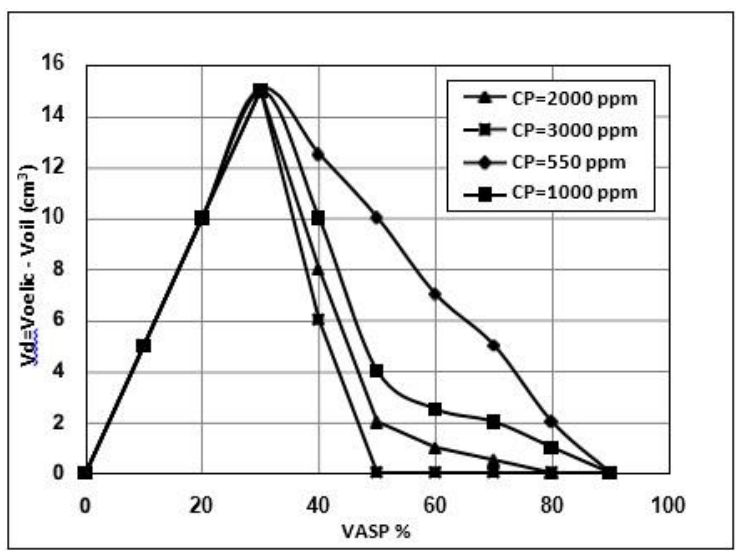

Figure 7 change of (Vd) relationship with (VASP\%) at all studied concentrations of (Xanthan Gum) polymer.

\section{Discussion of the results:}

The relation (Voleic with VASP\%) at the studied concentration of the polymer:

The (Voleic) value stays constant at its maximum (Full Emulsification) until the ratio (VASP $=30 \%$ ) for all the studied concentrations.

Above the (VASP $=30 \%$ ) a large decrease of (Voleic) occurs for (2000-3000 ppm) concentrations while the (Voleic) value decreases gradually and constantly for the (550 $\mathrm{ppm})$ concentration. For the (1000 ppm) concentration a slightly decrease of (Voleic) value occurs first followed by a significant decrease similar to what happens in case of (2000-3000 ppm) concentrations.

from above We conclude: that the concentration of (550ppm) is the optimum concentration of the polymer associated with the maximum volume of the single-phase area.

$>$ The relation (Vd with VASP\%) at different studied concentrations:

As (VASP\%) increased, the miscibility increases until the ration of $(30 \%)$ for the studied concentrations, then it decreases steeply regarding the $(1000,2000$ and 3000 $\mathrm{ppm}$ ) concentrations, while the decrease for the (550 ppm) is gradual and slight.

from above We conclude: that the optimum concentration of the polymer associated with maximum admixture is $(550 \mathrm{ppm})$. As the polymer concentration increases above $(550 \mathrm{ppm})$, the viscosity of the ASP solution increases while oil viscosity is constant which decrease miscibility due to the increasing difference in viscosity between the oil and the ASP solution.

\section{*The second stage:}

determination of the optimum concentration of each $P$ S-A within the ASP solution from the point of view of the phase behavior.

As we aforementioned, this stage aims to determine the optimum concentration of (Na2CO3) alkaline, [DDBSCa(Wetconat1220EH)]) surfactant and (Xanthan Gum) polymer in the ASP solution depending on the phase behavior. In another meaning, determination of the optimum concentrations that achieve maximum miscibility of oil with ASP injected solution in the formation. then, comparing these concentrations with those adopted in this study that were determined according to measurement of surface tension and viscosity as we aforementioned.

The study was divided into the following stages:

Firstly: studying the relation between the concentration of [DDBSCa (Wetconat1220EH)] surfactant in the ASP solution and the volume of the oleic phase (Voleic) that was formed.

Secondly: studying the relation between concentration of (Na2CO3) alkaline in the ASP solution and the volume of the oleic phase (Voleic) that was formed.

Thirdly: studying the relation between concentration of (Xanthan Gum) polymer in the ASP solution and the volume of the oleic phase (Voleic) that was formed.

Firstly: studying the relation between the concentration of the surfactant in the ASP solution and the volume of the oleic phase (Voleic) formed.

Procedures:

a) Preparing ASP solution with different concentrations of the surfactant while the concentration of the ( $\mathrm{Na} 2 \mathrm{CO} 3)$ alkaline and (Xanthan Gum) polymer are constant.

b) Adding a specific volume from every prepared solution (VASP) to a specific volume of oil (Voil) 
using a glass cylinders.

c) The cylinders are closed and after mixing for 24 hours they are left to settle (reach the equilibrium).

d) The volume of the resulted oleic phase ( $V$ oleic) is measured.

e) Plotting the relation between (CS) and The volume of the resulted oleic phase (Voleic)

f) All experiments are performed at the studied field temperature (DERO oil field) $(33 \circ \mathrm{OC})$ at a constant ratio of (VASP) volume to total volume (VT) equals to (28\%) which represents the current percentage of water in the produced fluid from DERO oil field.

g) By the end of this study the optimum concentration of the surfactant (Cs) that achieves maximum miscibility or maximum emulsification percentage between oil and ASP solution phases will be determined at the ratio (VASP/VT=28\%).

Results of this study are presented in the following table:

Table 14 results of measuring change of (Voleic \& $\mathrm{Vd}$ ) relationship with Cs at (VASP/VT $=28 \%$ ).

\begin{tabular}{|c|c|c|c|c|c|c|c|}
\hline $\begin{array}{c}\text { Sample } \\
\text { No. }\end{array}$ & $\begin{array}{c}\mathrm{Cs} \\
\% \mathrm{Wt} \\
\end{array}$ & $\begin{array}{l}\text { VASP } \\
(\mathrm{cm} 3) \\
\end{array}$ & $\begin{array}{c}\text { Voil } \\
(\mathrm{cm} 3) \\
\end{array}$ & $\begin{array}{l}\text { Voleic } \\
(\mathrm{cm} 3) \\
\end{array}$ & $\begin{array}{l}\text { Vaquas } \\
(\mathrm{cm} 3)\end{array}$ & $\begin{array}{c}\mathrm{Vd} \\
(\mathrm{cm} 3)\end{array}$ & Remarks \\
\hline 1 & 0.03 & 14 & 36 & 44 & 6 & 8 & \multirow{4}{*}{$\begin{array}{c}\text { Surfactant: } \\
\text { DDBSCa } \\
\text { Wetconat } \\
1220 \mathrm{EH} \\
\mathrm{CA}=\text { Const } \mathrm{CP}= \\
\text { Const } \mathrm{T}=33 \text { oC }\end{array}$} \\
\hline 2 & 0.05 & 14 & 36 & 50 & 0 & 14 & \\
\hline 3 & 0.1 & 14 & 36 & 50 & 0 & 14 & \\
\hline 4 & 0.2 & 14 & 36 & 50 & 0 & 14 & \\
\hline
\end{tabular}

Results visualization is presented in the following figures:

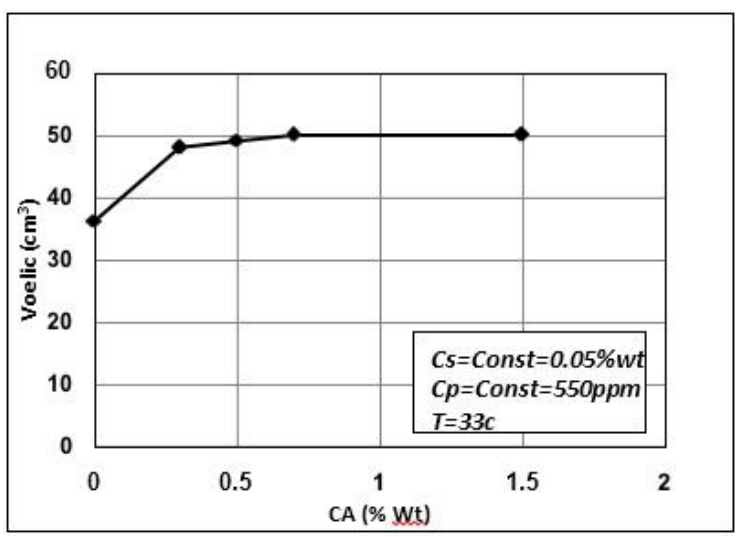

Figure 8 (Change of (Voleic) relationship with Cs at (VASP/VT $=28 \%$ ).
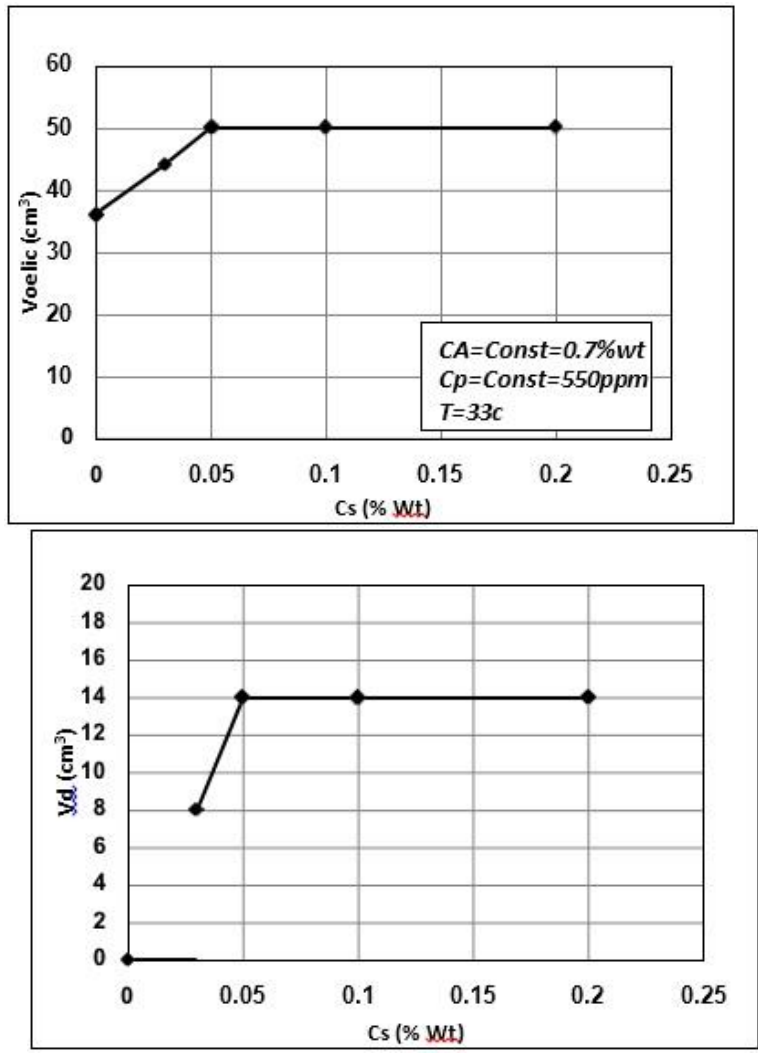

Figure 9 change of $(\mathrm{Vd})$ relationship with $\mathrm{Cs}$ at (VASP/VT $=28 \%$ ).

\section{Discussion of the results:}

The relation (Voleic with Cs):

We notice that the volume of single phase area increases as the surfactant concentration increases until ( $\mathrm{Cs}=0.05 \% \mathrm{wt}$ ). After this concentration, (Voleic) value stays constant as (Cs) increased from 0.05 to $0.2 \%$ wt.

\section{The relation (Vd with $\mathrm{Cs}$ ):}

Also we notice the increase of $(\mathrm{Vd})$ until $(0.05 \% \mathrm{wt})$ then stays constant as the (Cs) increases from 0.05 to $0.2 \% \mathrm{wt}$. therefore, the concentration $(0.05 \% \mathrm{wt})$ of [DDBSCa(Wetconat1220EH)] surfactant is the optimum concentration that lead to the maximum value of (Voleic) and maximum miscibility. This concentration is in accordance with the concentration of the said surfactant that gave minimum (IFT) at the borderline oil/ASP solution.

Conclusion: the concentration of the studied surfactant, which gave the maximum volume of the single phase area, is compatible with concentration that gives minimum (IFT) at (VASP/VT=28\%).

Secondly: studying the relation between alkaline concentration in the ASP solution and the volume of oleic phase (Voleic):

\section{Procedures:}

Several ASP solutions with different concentrations of ( $\mathrm{Na2} \mathrm{CO} 3$ ) alkaline are prepared while the concentration of [DDBSCa (Wetconat1220EH)] surfactant and (Xanthan Gum) polymer are constant . Later on, same procedures will be followed when studying the surfactant. 
Results of the experiments are presented in the following table:

Table 15 results of measuring change of (Voleic \& $\mathrm{Vd}$ ) relationship with (CA) at (VASP/VT $=28 \%$ )

\begin{tabular}{|c|c|c|c|c|c|c|c|}
\hline $\begin{array}{c}\text { Sample } \\
\text { No. }\end{array}$ & $\begin{array}{c}\text { CA } \\
\% \mathrm{Wt}\end{array}$ & $\begin{array}{c}\text { VASP } \\
(\mathrm{cm})\end{array}$ & $\begin{array}{c}\text { Voil } \\
(\mathrm{cm} 3)\end{array}$ & $\begin{array}{c}\text { Voleic } \\
(\mathrm{cm} 3)\end{array}$ & $\begin{array}{c}\text { Vaquas } \\
(\mathrm{cm} 3)\end{array}$ & $\begin{array}{c}\text { Vd } \\
(\mathrm{cm} 3)\end{array}$ & Remarks \\
\hline 1 & 0.3 & 14 & 36 & 48 & 2 & 12 & $\begin{array}{c}\text { Alkaline: } \\
(\text { Na2CO3) }\end{array}$ \\
\hline 2 & 0.5 & 14 & 36 & 49 & 1 & 13 & $\begin{array}{c}\text { (N) Const } \\
\text { CS=Const }\end{array}$ \\
\hline 3 & 0.7 & 14 & 36 & 50 & 0 & 14 & $\begin{array}{c}\text { CP= Const T=33 } \\
\text { oC } \\
\text { DERO Oil Field }\end{array}$ \\
\hline 4 & 1.5 & 14 & 36 & 50 & 0 & 14 &
\end{tabular}

Data visualization is shown in the following figures:

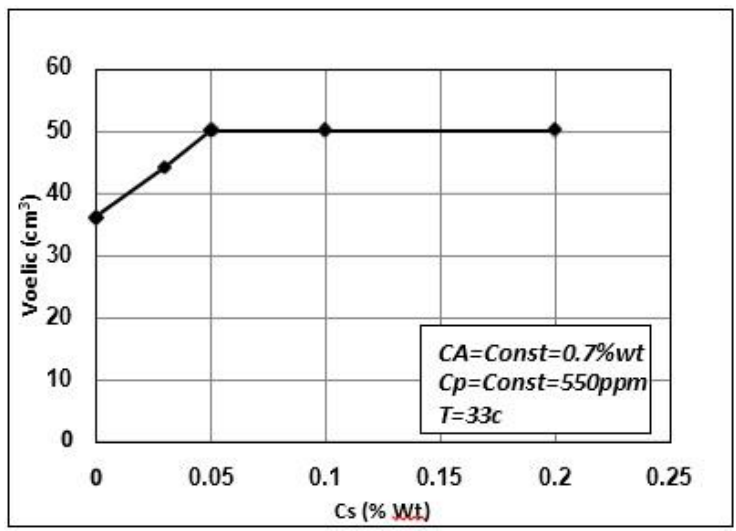

Figure 10 change of (Voleic) relationship with (CA) at (VASP/VT $=28 \%$ )

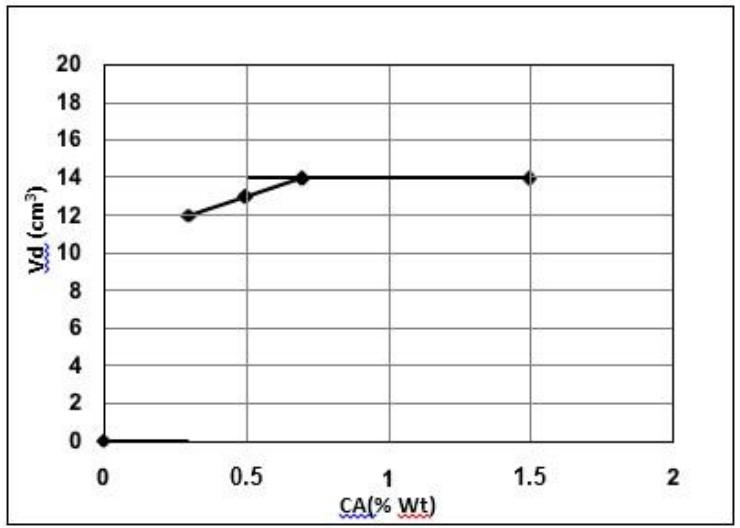

Figure 11 change of $(\mathrm{Vd})$ relationship with $(\mathrm{CA})$ at (VASP/VT $=28 \%$ )

\section{Discussion of the results:}

The relation (Voleic with $\mathrm{CA}$ ): we notice that as the (CA) increases the (Voleic) increases until the concentration $(0.7 \% \mathrm{wt})$ followed by a constant value of (Voleic) as the (CA) increases from (0.7 to $1.5 \% \mathrm{wt}$ ).

The relation (Vd with CA): a gradual increase of (Vd) occurs as the (CA) increases until the concentration $(0.7 \% \mathrm{wt})$ followed by a constant value of $(\mathrm{Vd})$ as the (CA) increases form ( 0.7 to $1.5 \% \mathrm{wt}$ ). Form all above we can conclude that the optimum concentration of (Na2CO3) alkaline that achieves maximum (Voleic \& $\mathrm{Vd})$ is $(0.7 \% \mathrm{wt})$ which is the same concentration of the said alkaline that achieved the minimum (IFT) at the boundary oil/ASP solution.
Thirdly: studying the relation between polymer concentration in the ASP solution and the oleic phase volume (Voleic):

Several ASP solution with different polymer concentrations and constant concentrations of ( $\mathrm{Na} 2 \mathrm{CO} 3)$ alkaline and [DDBSCa (Wetconat1220EH)] surfactant were prepared. Then, the same procedures when studying the surfactant were followed.

Results of the measurements are presented in the following table:

Table 16 results of measuring change of (Voleic \& Vd) relationship with $(\mathrm{Cp})$ at (VASP/VT $=28 \%)$

\begin{tabular}{|c|c|c|c|c|c|c|c|}
\hline $\begin{array}{l}\text { Sample } \\
\text { No. }\end{array}$ & $\begin{array}{c}\mathrm{CP} \\
\mathrm{ppm}\end{array}$ & $\begin{array}{l}\text { VASP } \\
(\mathrm{cm} 3)\end{array}$ & \begin{tabular}{|c}
$\begin{array}{c}\text { Voil } \\
(\mathrm{cm} 3)\end{array}$ \\
\end{tabular} & $\begin{array}{l}\text { Voleic } \\
(\mathrm{cm} 3)\end{array}$ & $\begin{array}{l}\text { Vaquas } \\
\text { (cm3) }\end{array}$ & $\begin{array}{c}\mathrm{Vd} \\
(\mathrm{cm} 3)\end{array}$ & Remarks \\
\hline 1 & 550 & 14 & 36 & 49.5 & 0.5 & 13.5 & \multirow{4}{*}{$\begin{array}{c}\text { polymer: } \\
\text { Xanthan Gum } \\
\text { Cs }=\text { Const } \\
\mathrm{CA}=\text { Const } \\
\mathrm{T}=33 \text { oC } \\
\text { DERO Oil Field }\end{array}$} \\
\hline 2 & 1000 & 14 & 36 & 49.5 & 0.5 & \begin{tabular}{|l|}
13.5 \\
\end{tabular} & \\
\hline 3 & 2000 & 14 & 36 & 49.5 & 0.5 & 13.5 & \\
\hline 4 & 4000 & 14 & 36 & 49.5 & 0.5 & 13.5 & \\
\hline
\end{tabular}

Data visualization is presented in the following figures:

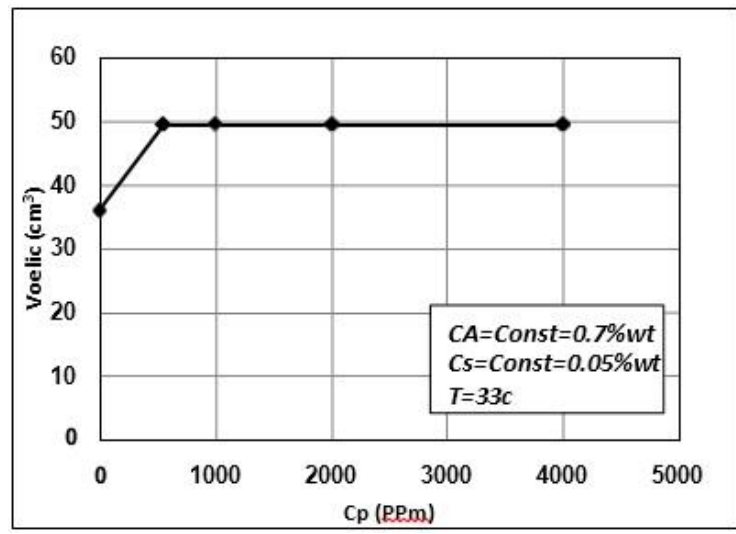

Figure 12 (change of (Voleic) relationship with $(C p)$ at (VASP/VT $=28 \%$ )

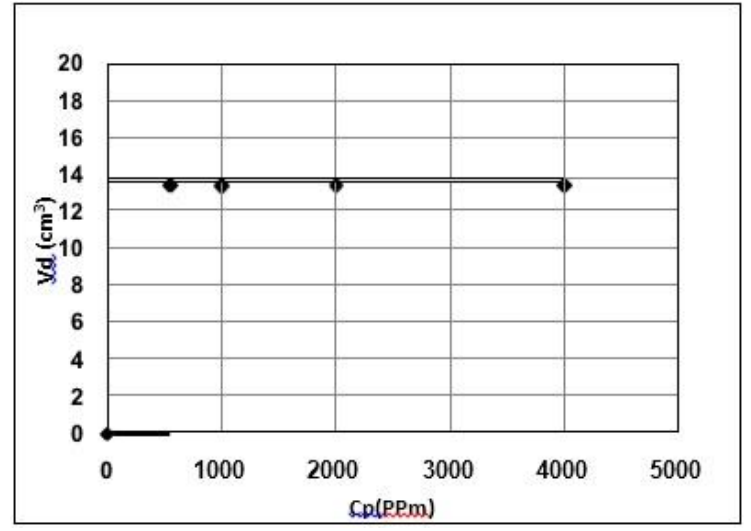

Figure 13 change of $(\mathrm{Vd})$ relationship with $(\mathrm{Cp})$ at (VASP/VT $=28 \%$ )

\section{Discussion of the results :}

The relation (Voleic with $\mathrm{Cp}$ ): as the $(\mathrm{Cp})$ increases, the (Voleic) increases until the concentration (550 ppm) then stay constant until (2000 ppm). 
The relation (Vd with $\mathbf{C p}$ ): as the $(\mathrm{Cp})$ increases, the (Vd) increases until the concentration (550 ppm) then stay constant until (2000 ppm). Form all above, we conclude that the optimum concentration of the polymer that achieve maximum miscibility and maximum volume of the single phase area is (550 $\mathrm{ppm}$ ) which is the same concentration that gave a viscosity corresponding the oil viscosity of DERO oil field.

\section{Conclusion:}

from all the above study we can conclude the following important result:

The optimum concentrations of $\mathrm{A}-\mathrm{S}$ - $\mathrm{P}$ within the ASP solution that achieve maximum miscibility with oil are compatible with the concentrations we found for A- S - P that achieved:

minimum interfacial tension at minimum concentration (regarding surfactant and alkaline) .

maximum viscosity compatible with oil viscosity of the studied oil field at minimum concentration (regarding the polymer).

Thus, the determination of the optimum concentrations of the components of the ASP chemical injection solution can be determined easily through the study of the phase behavior without the need for lab devices to measure surface tension and viscosity that may not be available in an oil field.

These A - $\mathrm{S}$ - $\mathrm{P}$ concentrations reached through this study will be used in the lab displacement processes because it fulfills the following conditions:

1. Minimum interfacial tension.

2. Maximum miscibility.

\section{REFERENCES}

[1] D.L.Zang,Sliu"Favorable Attributes Of AlkalineSurfactant-Polymer Combination Flooding " SPE 2006.

[2] Songwanchao, Yang Chengzhi "Alkaline- SurfactantPolymer Combination Flooding For Improving Recovery of The Oil" SPE 1995.

[3] YaunShiyi,YangHau "Effects Of Important Factors On Alkaline/Surfactant/Polymer Flooding" SPE 1998.

[4] Gao, Shutang, Li Huabin

"Laboratory Investigation of

Combination of

Alkaline/Surfactant/Polymer Technology For Daging EOR" SPE 1995

[5] Nelson, And Pope"Phase Relations In Chemical Flooding" SPE 1978

[6] Shuler, P.J, Kuehne, D.L, And Lernen, Nil "Improving Chemical Flooding Efficiency With Micellar/Alkaline/Polymer Processes" SPE 1984.

[7] Sayyouh, M.H, Abdel Waly, J. And Salama "Design Of Micro emulsion Slug For Maximizing Tertiary Oil Recovery Efficiency" SPE 1991.
[8] Nelson, R.C "The Salinity Requirement Diagram- A Useful Tool In Chemical Flooding Research And Development" SPE 1982.

[9] A.M.Attia" Phase Behavior of surfactant/oil/water system in enhanced oil recovery"1995

[10] Maura, C.P And Ronald "A Three Parameter Representation of Surfactant- Oil- Brine Interactio" SPE 1982.

[11] Healy,R.N And Reed,R.L"Physiochemical Aspects Of Micro Emulsion Flooding" SPE 1984.

[12] Salter, S.J "Optimizing Surfactant Molecular Weight Distribution 1.sulfonate Phase Behavior And Physical Properties" SPE 1983.

[13] Krumrine, P.H " Surfactant, Polymer And Alkaline Interactions In Chemical Flooding Processes" SPE 1983.

[14] WanLi Kang, Demin Wang "Emulsification Characteristic And De- Emulsifiers Action For Alkaline/Surfactant/Polymer Flood" SPE 2001.

[15] Matrine, J.Coxly "Effect Of Various Alkaline Chemicals On Phase Behavior Of Surfactant/Oil/Brine Mixtures" SPE 1985.

[16] Ashrawi,S.S"AStudy Of The Relation Between Surfactant/Oil/Brine/System Phase Behavior And Chemical Flood Recovery In Short Cores" Oklahoma 1984.

[17] Trashenski,S.P"Miceelar Flooding: Sulfonate-Polymer Interaction" New York 1977. 18-Sazabo, M.T "The Effect Of Surfactant/Polymer Interaction On Mobility Buffer Design" SPE 1979.

[18] Sazabo, M.T "The Effect Of Surfactant/Polymer Interaction On Mobility Buffer Design" SPE 1979. 